\title{
Rolling Over into the Age of Algorithm*
}

\author{
Francisco J. Dalby \\ Advanced Dynamics C.B., Madrid, Spain \\ Email: gestor@advanceddynamics.net
}

How to cite this paper: Dalby, F.J. (2017) Rolling Over into the Age of Algorithm. World Journal of Mechanics, 7, 39-42. https://doi.org/10.4236/wjm.2017.73005

Received: December 27, 2016

Accepted: March 10, 2017

Published: March 13, 2017

Copyright $\odot 2017$ by author and Scientific Research Publishing Inc. This work is licensed under the Creative Commons Attribution International License (CC BY 4.0).

http://creativecommons.org/licenses/by/4.0/

\begin{abstract}
This paper is an extract of the prologue to the book: New Paradigm in Physics - Theory of Dynamic Interactions [1], published by Gabriel Barceló. This summary describes the elements that constitute the characteristics of the Theory of Dynamic Interactions, and certain circumstances of it. The author recalls that the Theory of Dynamic Interactions arrives at unheard of conclusions which, even with the level of dissemination reached by this theory over recent years, have not been scientifically refuted.
\end{abstract}

\section{Keywords}

Theory of Dynamic Interactions, Spinning Top, Boomerang, Hula Hoop, Celestial Bodies, Use of Data, Rotating Object, Non-Concurrent Accelerations

The Theory of Dynamic Interactions (TDI) [2] explains the behavior of rotating bodies; the reason why, when these bodies are subject to new stimuli that do not share their axis of rotation, an intriguing, different and simultaneous movement is generated. This refers to a behavior that remained unexplained by the conventional laws of physics known until then.

The effect is shown with the movement of the spinning top and the boomerang [3]; with the pebble which, when having been thrown in such a way as to spin, rebounds several times with renewed energy when hitting the surface of the water; it is also illustrated by the hula hoop ring which does not fall to the ground as long as it remains rotating around the thrusting waist of the dancer. How is it possible not to have one's attention awakened by something that evokes paradigms practically forgotten from your childhood?

There are numerous examples of TDI around us [4].

Even though we do not go around thinking about it all the time, we are all aware of the movement of rotation and translation in which are immersed in the

*This is an extract of the Prologue of the book new paradigm in physics-theory of dynamic interactions by Gabriel Barceló (Amazon, 2017). 
world that surrounds us.

Celestial bodies in orbit that rotate around themselves enter into the field of application of this theory. Indeed, the same can also be said of the structure of the atom.

What is more, extremely useful predictions could even be made, if it was possible to show that the hypotheses, theorems and laws governing this new theory were a valid representation of the world that surrounds us.

TDI was publicly expounded for the first time at the $30^{\text {th }}$ Orense Biennial Physics Conference in Spain in 2005. Nonetheless, the most immediate advancement came about afterward in the field of publishing. Publications account for a great part of Gabriel Barselo's endeavors over these years. The first book, The Flight of the Boomerang (2006) paved the way for four more; one of which, Imago Universi (2013), took the form of a comprehensive treatise on the history of science and of the sources that served as an inspiration to position and better explain TDI itself.

From a TDI perspective, the development of physics has been slowed down by Newtonian theories in a field as important as rotational dynamics. That is to say, with respect to the physics of rotating bodies, which moves the entire universe as I mentioned above, a sort of investigative standstill took place in the science nowadays considered as classical. Until now, certain behavioral patterns of these rotating bodies have been considered as anomalous, or "paradoxical", as was the gyroscope branded by a particular scientific treatise.

Scientific evolution, like that of civilization in general, is not continuous. It takes place in spurts, followed by barren periods, making continuous forays into the desert only to be followed by exponential outbreaks, such as we are experiencing nowadays, with an unprecedented access to knowledge, information and hyper connectivity.

TDI came on the scene at the dawning of the new 21st century, as a further manifestation of the marked character of this century.

The 21st century has seen the industrial economy step aside to make way for the knowledge economy, which as is well known, is constantly enlivened by globalization, information and innovation. It has come with the bursting onto the scene of the Internet and a hitherto unheard of level of intercommunication to achieve an exponential evolutionary process in so many spheres of daily life.

Nowadays, new industries are continually sprouting up into which enormous sums are being invested in the form of official aid, along with the resources of already existing large corporations, not to mention the extensive presence of venture capital. Of these new industrial projects and the destinations of the new investment only one, robotics, attracts the attention owing its certain level of "materialness". Indeed, the robot has also burst onto the scene to reduce, as far as possible, the workforce, the time taken and the use of materials (it should also be noted that robots are becoming increasingly smaller in size). Most other inventions are to a greater or lesser extent involved with making the most of ever-changing virtual knowledge. 
A lot of these new companies, the majority of which are multi-national oriented, are in essence program platforms for data handling purposes. Basically, the aim is to cut middleman costs and achieve greater speed in getting the end product or service. In the $21 \mathrm{st}$, investment is mostly on the up in intangible assets.

One of the targets for new investments, along with those dedicated to medical applications in the study of the human genome and biotechnology, is the coding of systems with a view to achieving greater accuracy in operations. This coding will make it possible to achieve greater security-notably cybersecurity-and also, above all, to achieve the greatest possible speed.

Digitalization marked the 20th century and the coding of that digitalization is set to become the endeavor of the 21 st century. Data are the raw materials of our age, as earth and iron were of others. It is now striking how, at first, the entire economy was agricultural and then, already in the 19th century, at the dawn of the industrial revolution, casting which began in northeastern England, and which in hindsight, seems to be something as basic as is the management and use of iron, would give rise to the chain, the pulley, the machine, the railway, the tool, in short, mechanization.

But what is most important at present is that enormous amounts of data are being generated the whole time. It is the investigation and use of these data, the so-called big data that has become one of the main targets for investment.

In short, the current century can be defined as a century of investigation in the intangible and in the smart use of data. Making use of knowledge becomes possible when this has been coded and transformed into a model with general rules, laws and theorems that presumes to be a valid representation of the world that surrounds us; that is to say, an algorithm that digests and uses that knowledge.

For TDI, the source of data is generated by any rotating object.

TDI develops an aspect of the classical theory of Newtonian physics that still remains unresolved by means of general rules and its own algorithm.

$$
\vec{v}=\vec{\Psi} \vec{V}_{0}
$$

The rotational dynamics phenomena described by TDI have still not been incorporated into the rational structure of current orthodox physics. Accordingly, TDI is an innovative approach that makes scientific and technological progress possible in an important part of the world that surrounds us.

To date, scientific literature has not announced the conclusions reached by TDI in its study of systems and rigid solid bodies subject to external actions that generate simultaneous, spatially non-concurrent accelerations. TDI arrives at unheard of conclusions which, even with the level of dissemination reached by this theory over recent years, have not been scientifically refuted, at least to our knowledge, by anyone.

There are practical applications of TDI that have already been identified by G.B. and his promotional setting [5]. Some of them have been materialized in 
prototypes and patents. However, there are as many other applications as there are different types of rotating objects that exist in the world about us. No doubt time will show that there are many more.

\section{References}

[1] Barceló, G. (2017) New Paradigm in Physics, Volume I. Amazon, Madrid.

[2] Barceló, G. (2008) A Rotating World. Marcombo, Barcelona. http://www.dinamicafundacion.com/

[3] Barceló, G. (2006) The Flight of the Boomerang. Marcombo, Barcelona. http://www.dinamicafundacion.com/

[4] Barceló, G. (2013) Imago Universi: A Story of the Human Conception of the Cosmos. Arpegio, Barcelona. http://www.editorialarpegio.com/. http://imagouniversi.com/

[5] Barceló, G. (2013) Proposal of New Criteria for Celestial Mechanics. International Journal of Astronomy and Astrophysics, 3, 385-391.

Submit or recommend next manuscript to SCIRP and we will provide best service for you:

Accepting pre-submission inquiries through Email, Facebook, LinkedIn, Twitter, etc. A wide selection of journals (inclusive of 9 subjects, more than 200 journals)

Providing 24-hour high-quality service

User-friendly online submission system

Fair and swift peer-review system

Efficient typesetting and proofreading procedure

Display of the result of downloads and visits, as well as the number of cited articles

Maximum dissemination of your research work

Submit your manuscript at: http://papersubmission.scirp.org/

Or contactwjm@scirp.org 